\title{
ANNOTATIONS
}

\section{The Centenary of the Lancet}

The Lancet was born on Sunday, October 5, 1823, and celebrated its hundredth birthday in the issue dated October 6, 1923. And what a celebration it is! There must be few periodicals which have retained their original title and their main objectives intact for 100 years. In spite of the editorial disclaimer that "it makes no pretence to being a history of medicine during 100 years," the fascinating Supplement which forms the bulk of the Centenary number of the Lancet constitutes a veritable history of all that has happened of importance in a century of publication. The large share taken by the Lancet in these happenings, through the virile personality of its first proprietor and editor, Thomas Wakley, and through the unswerving loyality to his aims, if not always to his methods, of his successors, has rendered it possible to construct a connected story of the history of medical progress from the columns of the journal.

How Thomas Wakley was stimulated by misfortune to endeavour to redress grievances and to right the wrong must be read in full to be appreciated. When a man of strong character feels it his duty to redress wrongs his methods are apt to be the reverse of gentle, and this was so in Wakley's case. It has been said by a lay contemporary that the title Lancet suggests the cutting away from the body politic of any offensive growth. After reading the story of the first ten years when "the Lancet.was a duelling ground for a series of fierce encounters between the Editor and the privileged classes in medicine" we incline to the view that the blood letting uses of the instrument must have been the source of the title. In the first ten years the paper was engaged in ten actions at law. Six were for libel, the aggregate sum claimed being $£ 8,000$. Yet so true in substance and in fact were the Lancet's statements regarding nepotism and malpractice at the hospitals, though they were sometimes couched in the most provocative language possible, that the aggregate amount of damages awarded was only $£ 1550 \mathrm{~s}$. $0 \frac{1}{4} \mathrm{~d}$.

It is clear that the present editorial staff has suftered from an embarrassment of riches in preparing the Supplement, for, while the latter extends to 154 columns of the current number, it has not been found possible to govinto such detail in the later sections as in the earlier, when "personalities and things were under notice which" could not be objects of memory to many living."

It is impossible in a short annotation to summarize this centuryembracing Supplement. We can only recommend to every member of the medical profession that he possess a copy of this number of the Lancet and, after reading it, make a mental comparison of things as they are to-day with what might have been 
had not Thomas Wakley (1823-1862), his sons, James (1862-1886) and Thomas H. Wakley (1886-1905), and his grandson, Thomas Wakley, Jun. (1886-1908), and the present editorial staff initiated and carried on a campaign, first of all against the leaders of the medical profession itself and, afterwards, against all that was inimical to the medical profession and to the public interests. But, as the lay contemporary already referred to remarks, "on its hundredth birthday the Lancet has the reputation of being a serious and solemn medical newspaper. There is no sign at all in its careful pages of that romantic, violent, but withal, splendid past which was so very well known to our grandfathers." Times have changed and we with them. The fierce battle has been fought for the right, and the energy formerly directed towards reformation has been largely redirected towards information. Following upon the exposure of nepotism and malpractice, laziness and greed amongst the leaders of the profession, came the organized movement against tuberculosis, the treatment of insanity, the exposure of food adulteration by means of the Lancet Sanitary Commission, the enquiry into Workhouse administration, anaesthetics, Listerism, the foundation of Epsom College, the Medical Act of 1886, the registration of midwives and so on up to the present time; in all of which movements and discoveries the Lancet has taken a hand and often played a trump card. What with the domestic history of the Journal, the history of its activities, the sketches of character of past medical masters and the reproduction of their features (there are some fifty of these portraits including a colour reproduction of a Landseer sketch of Thomas 'Nakley) one cannot find a dull moment in the perusal of this, surely the most important piece of medical journalism ever attempted.

\section{Monograph Supplements}

Papers which are too long for insertion in one or even two numbers of this journal are occasionally submitted to the Editorial Committee. The subdivision of such papers is always unsatisfactory and often leads to less than proper justice being accorded to them. In some cases it would be quite impossible for the journal to allot the necessary space. The Editorial Committee has in several instances been forced to refuse monographs which were well worthy of publication owing to this cause. It has, therefore, been arranged, with the sanction of the Directors, to issue from time to time Monograph Supplements. These will be published in the same form as the journal, and will be issued at a reduced price to subscribers to the journal. We have pleasure in announcing that the first Monograph Supplement, now ready. is the Gifford Edmunds Prize Essay on Interstitial Keratitis, by Mr. W. T. Holmes Spicer. 